\title{
クメール棟瓦造遺跡の棟瓦組積技術研究 \\ THE STUDY OF ANCIENT TECHNIQUES ON KHMER BRICK TEMPLES
}

\author{
朴 東 熙*, 中川 武**, 下田一太吕*
}

Donghee PARK, Takeshi NAKAGAWA and Ichita SHIMODA

\begin{abstract}
From 7 to 10th century, the brick religion monument had been formed actively in Cambodia. The structure dating from same period of the time has been still remained but the succession of technique has been disconnected and this situation led to restore the ruins difficulty. This study focuses on the masonry construction technique among the ancient techniques used on Khmer ruins and determines what kinds of techniques were imposed. Furthermore, this study considers how each technique had been used and changed with the times.

The object of investigation is the 36 of Khmer brick the structures were built from 7th to 10th century. According to the survey results, common technique had been used annually and the changed technique had been used by lapse of time. The common technique is called by 'the grid-masonry technique' that is the adhesive face would be rubbed each other and stick to construct and to use 'the completed brick' that is last member of framework. The other hands, we observed the changed techniques that make a height balance between floors and adapt a grade of wall horizontally with time. Then, we survey the masonry brick pattern and the ended technique with plaster mortar for find out the relationship with the alteration of masonry brick technique.
\end{abstract}

Keywords:,Brick structure, Construction Techniques,Restoration, Southeast Asia 煉瓦構造，古代建築技術，修復，東南アジア

\section{1. 研究背景}

7 世紀初頭から 10 世紀末までカンボジアでは煉瓦を用いた宗教 建築が盛んに造営された。ヒンドゥー・仏教文化の導入とともに始 まったと考えられる煉瓦建築技術は自らの発展を重到、クメール独 自の建築様式および施工技術を確立した。しかし、10 世紀を前後と し、重要な寺院は煉瓦造から砂岩造へ転換される過程のなかで、煉 瓦造建築に使用された建築技術の一部は砂岩造建物にも継承された が 1)、煉瓦造建築では技術的な更新機会は失った。

最近 20 年あまり、カンボジアでは国際的な支援にもとづく古代 クメール遺跡の保存修復活動が活発に行われている。1990年代にお いては危機にさらされた遺跡を対象に応急措置を目的とした修復活 動が主であった。しかし、最近では重要遺跡の多くはある程度さし 迫った危機から脱し、応急的な補強措置もかなり行き届くようにな ってきたと思われる。カンボジアでの保存修復活動は、国際的に論
議されてきた保存哲学にもとづき、修復方法が選択され理念が構築 されてきた。その理念の一つが古代の技術を究明し、できるかぎり その技法にもとづく修復工事の実施である。そのためには、修復工 事に先立ち，古代の建造技術を解明寸ることが不可欠である。本稿 では、クメールの煉瓦造遺跡を修復するために、煉瓦の組積に適用 された技術を明らかにすることを試みる。

\section{2. 先行研究}

今日のベトナム南部に位置する扶南遺跡においては煉瓦造の基礎 が報告され 2)、東南アジアにおける煉瓦造建築の最初期の構造を見 ることができる。クメール建築における煉瓦建築の建造が直接的に インドからの影響を受けたことによるものか、あるいは扶南や今日 のタイに分布するドヴァラヴァティ等の煉瓦造遺構を通じた二次的 な影響によるものかは定かでないが，サンボー・プレイ・クック
* 日本学術振興会特別研究員 早稲田大学建築史研究室 博士後期課程

** 早稲田大学理工学部教授 工博

*** 筑波大学大学院人間総合科学研究科 助教 $\cdot$ 博士 (建築学)
Research Fellow of the Japan Society for the Promotion of Science

/Laboratory of Architectural history Waseda Univ. Ph.D. Candidate. Eng Prof. of Faculty of Science \& Engineering, Waseda Univ., Dr. Eng

Assist. Prof., Graduate School of Comprehensive Human Science, University of Tsukuba, Dr. Arch 
(Sambor Prei Kuk)遺跡群における煉瓦造建築の中にはその装飾様 式においてインド的な色彩が濃いものも認められ，直接的な建築技 術の受容であった可能性をうかがわせる。

プレ・アンコール期からアンコール期に至る間のクメール煉瓦建 築には多くの変化が見られる。構造的に脆弱な開口部および屋蓋部 の改良を通じて、徐々に安定性を高める工夫が加えられた ${ }^{3)}$ 。また、 プノム・クレンおよびコー・ケーなどの一部地域ではチャンパ煉瓦 建築の特徽である壁弇 4)が現れるなど、周辺国の影響として考えら れる変化も観察される。

クメールの煉瓦造建築にみられる組積技術は一般的に日本および ヨーロッパ文化圈で見られる煉瓦造建築とは異なる特徴を持つ。ま ず、使われた煉瓦の大きさが一定ではなく、規則的な組積パターン を見出すことも難しい。また、内外の外装面にあっては煉瓦間に漆 喰モルタルのような接着剤もしくは充填剂が観察できず、密着した 組積である。煉瓦間に用いられた接着剤はリアナ(Liana)の樹液と砂 糖ヤシを混合した薄いバインダーであるとする説や5)、トンレサッ プ湖で生産される貝殼を利用した消石灰系接着剤である説 6)、チュ ーティエル(Cheateal)の樹液を用いたという説 7)、シロアリの巣を 混合したという説などがある。こうした天然資源の材料を利用した 修復事例もある 8)。しかし、科学的に接着剤の原材料の特定に成功 した事例はまだ報告されてない注1)。

組積方法に関する研究事例は少ないが、J.DUMARCAY は組積過 程にて少量の水を使用したと推測している 9)。また、チェン・ラタ は煉瓦壁の構成が 8 世紀末までは 3 層に別れていたが、9世紀から は煉瓦を組み合わせて壁を一体化することで耐久性を高めたとする 技術的改善の過程を示した ${ }^{10)}$ 。

クメールにおける煉瓦造建築の構造と構造の変化に着目した編年 考察についてはチェン・ラタによる論考がある ${ }^{11}$ 。開口部の構造の 変化に着目し、7 10 世紀の建築を 7 9 世紀後半、9 世紀末、そし て 10 世紀初頭 10 世紀半ばに分類した。また、平面図と屋蓋部の 形、そして壁体の構造変化に基づき、7 8 世紀末、 9 世紀初頭 9 世 紀後半、9 世紀末 10 世紀半ばに区別した。このような変化を総合 的に分析し、クメールの煉瓦造建築は7 9世紀にかけて改良を重ね、 10 世紀半ばには技術的に絶頂期を迎えたものと評価した。アンコー ル王朝の隣国であり、クメール建築との相互的な関係があった可能 性が高いチャンパ煉瓦造建築における重枝による煉瓦造建築の構造 変化による編年の考察も貴重な比較考察として挙げられる ${ }^{12)}$

クメール煉瓦造建築に用いられた組積技術は他の文化圈とは異な る特殊性を持つが、研究は未だに極めて初期的な段階にある。した がって、本稿ではクメール煉瓦建築に使われた建造技術の詳細を明 らかにしようとするものである。

\section{3. 研究対象遺構}

研究対象はサンボー・プレイ・クック遺跡群 $(7$ 世紀注 2$)$, コンポ ン・トム(Kompong Thom)州の煉瓦遺跡(8世紀), ロルオス(Roluos) 遺跡群(9世紀), アンコール(Angkor)のプレ・ルプ(Pre Rup)と東メ ボン(East Mebon)の煉瓦建造物 (10 世紀)である。また追加考察のた め 10〜11 世紀に建立されたとする説がある Robang Romeas(ロバ ン・ロメアス)注3)を加え、計 36 基を対象とした注4)

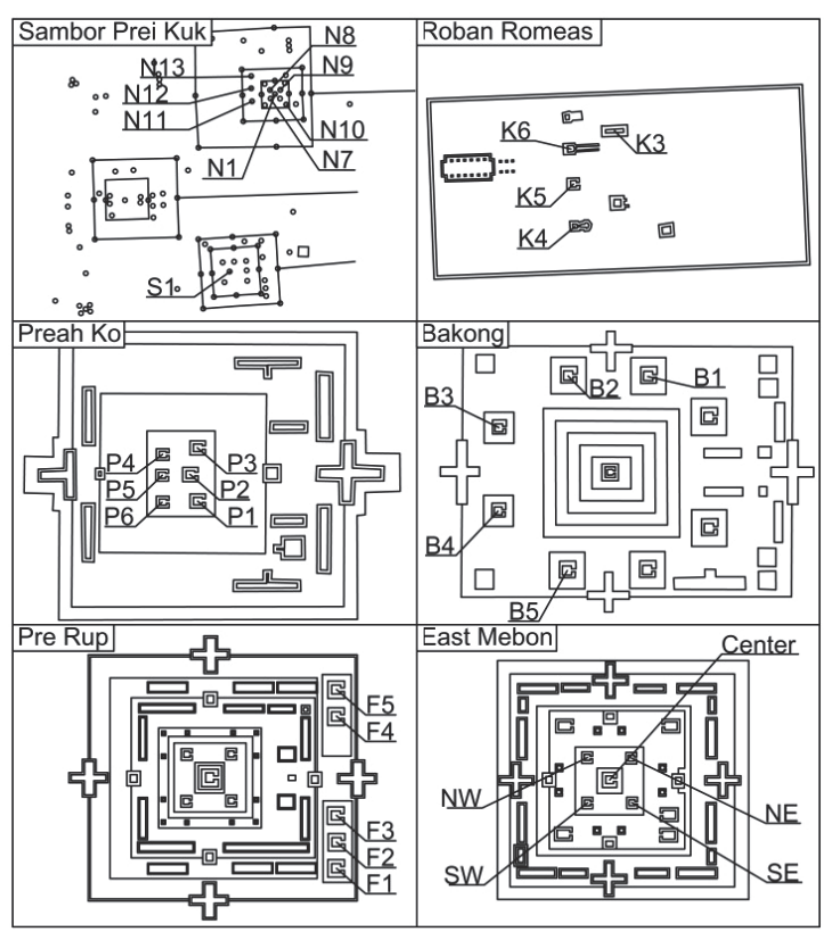

図 1 対象遺跡の簡略平面図と対象遺構注 5 )

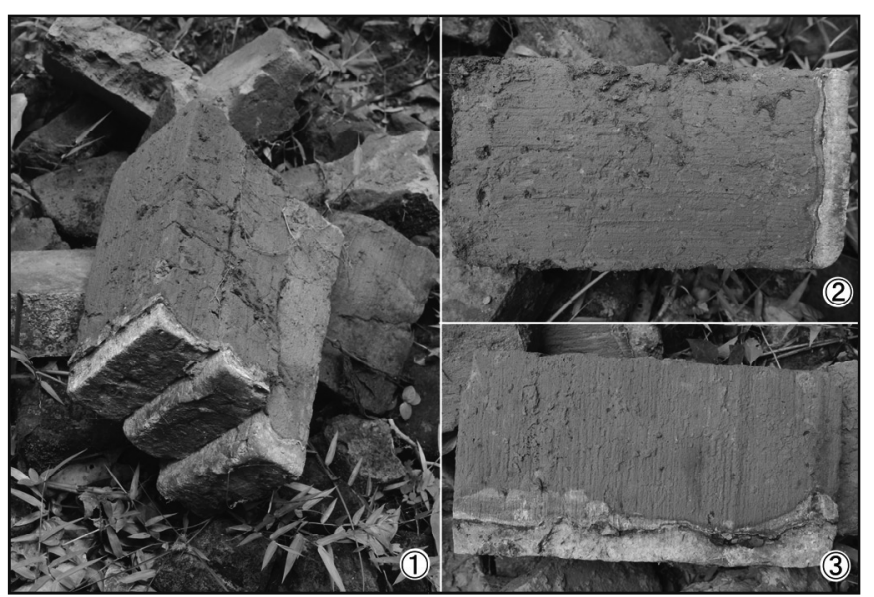

図 2 N12 寺院で観察された煉瓦の接着面

(1)付着状態を維持している煉瓦サンプル

(2)(3)煉瓦の接着面で観察できる研磨痕跡、研磨方向(2)は↔、(3)は1 ※写真の白い部分が煉瓦構造の外面であった部分である。

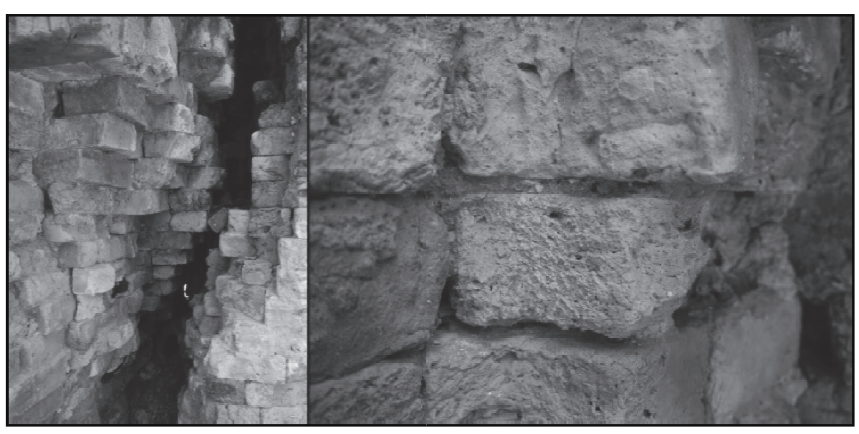

図 $3 \mathrm{~N} 13$ 寺院の亀裂箇所 (外壁西側)、 壁体内部煉瓦の接着箇所で観察されたモルタル 


\section{4. 煉瓦組積に適用された技術調査}

\section{1. 研磨組積技法}

ほとんどのクメールの煉瓦遺構の外装煉瓦積みの目地ではモルタ ルが観察されず、密着した状態として観察される。2013 年 6 月に 部分的な崩壊が発生したサンボー・プレイ・クック N12 寺院で、煉 瓦接着面を観察した。接着面の状態を図 2 に示す。

複数の煉瓦が密着した状態で散乱した 5 つのサンプルを 2 つに き分け接着面を観察した(図 2)。接着面では粘土粒が特定方向に整列 していた。またその粘土粒はところどころ丸まった状態で煉瓦の小 さな溝もしくは隙間を充填していた。研磨の方向は露出していた外 壁(図 2 の白い部分)と垂直方向であった(図 2.(2),(3)。

上記の観察を通じて外装面の煉瓦の組積には「研磨組積技法」が 使われたと推測した。研磨組積技法とは煉瓦と煉瓦を摩擦させ接着 面を緻密に密着させる組積技術である。煉瓦粉が丸まった状態で 固着しているのは研磨過程で水が使われたからであると考えられる。 また、確認できた個数は限られているが、すべての接着面にて観察 できる粘土粒の整列方向が壁面と垂直方向であることから煉瓦の研 磨が壁面と垂直な方向に行われたことが推測される。

\section{2. 接着剤の使用に関する調査}

煉瓦の組積に用いられた接着技術は少なくとも 2 種類以上あると 考えられる。前述した外装の煉瓦の接着面が密着した部分にて使わ れた接着技術と、壁体内部の密着してない煉瓦組積に使われた 充填 モルタル接着技術である(図 3 )。この 2 つの接着技術に使われた接 着剂の組成を調べた。

4.1 にて観察した煉瓦接着面で粘土粒 $(\mathrm{A}) 、$ 粘土粒が付着していた 煉瓦(B)、サンボー・プレイ・クック N13 の崩壊した壁体内部で採 集した充填用モルタル $(\mathrm{C})$ の化学組成分析 $(\mathrm{XRF}$; 蛍光 $\mathrm{X}$ 線分析)を行 った。結果は表 1 の通りである。

分析結果から、A と B は同じ成分であると考えられた。またその 結果はサンボー・プレイ・クックで使われた煉瓦の一般的化学組成 $\left(\mathrm{SiO}_{2}\right.$ 81 92wt\%, $\mathrm{Al}_{2} \mathrm{O}_{3}$ 5 12 wt\%, $\mathrm{Fe}_{2} \mathrm{O}_{3}$ 0.8 2.4 wt\%) $\left.{ }^{14}\right)$ と類似す ることが確認できた。すなわち、観察された粘土粒は煉瓦の研磨過 程で発生した煉瓦粉であることが破認できた。また 分析結果から密 着した煉瓦での接着剤使用の有無を判断できる情報は得られなかっ た。一方、充填モルタル $\mathrm{C}$ は $\mathrm{SiO}_{2}$ の含量が $\mathrm{A}, \mathrm{B}$ と比べて低いなど、 $\mathrm{A} ＼textrm{B}$ とは異なる材料であることがわかった。しかし、 Ca の含量は $\mathrm{A}, \mathrm{B}$ と類似したレベルであり、石灰系の混合物が追加されたとは考 えられない。

\section{3. くさび用煉瓦の使用}

前述の通りに外装面の煉瓦は研磨して組積されるため、煉瓦の大 きさが一定でなくなる。また、煉瓦各層の組積を完結させて閉じる ためには最後に余った空間に合う大きさの煉瓦が必要となる。その 余った空間を閉じるために使われた煉瓦を本稿では「くさび用煉瓦」 と称する。

くさび用煉瓦を観察することで各層の煉瓦の組積順序を知ること ができる。くさび用煉瓦はほとんどの壁面の端部より内側で観察さ れる。一層の組積順序は図 5 の通りに各面の両端から始まり壁面内 側で終わる規則性を持つ。
表 1 XRF 分析による組成成分 (unit:wt\%)

\begin{tabular}{|l|l|l|l|l|l|l|}
\hline & $\mathrm{SiO}_{2}$ & $\mathrm{Al}_{2} \mathrm{O}_{3}$ & $\mathrm{FeO}$ & $\mathrm{K}_{2} \mathrm{O}$ & $\mathrm{CaO}$ & Etc. \\
\hline $\mathrm{A}$ & 81.9 & 12.7 & 2.2 & 0.7 & 0.2 & 2.3 \\
\hline $\mathrm{B}$ & 78.0 & 13.6 & 2.0 & 0.7 & 0.3 & 5.4 \\
\hline $\mathrm{C}$ & 67.8 & 14.4 & 1.4 & 1.6 & 0.3 & 14.5 \\
\hline
\end{tabular}

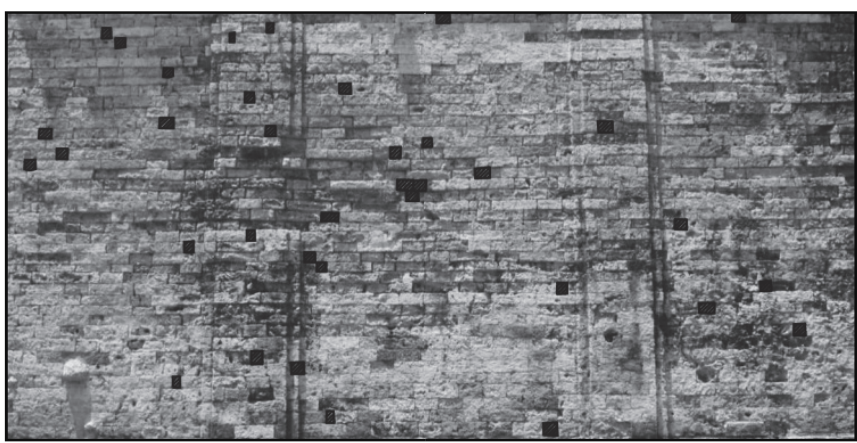

図 4 SamborN9 寺院で見られるくさび用煉瓦の位置 (外壁西面)

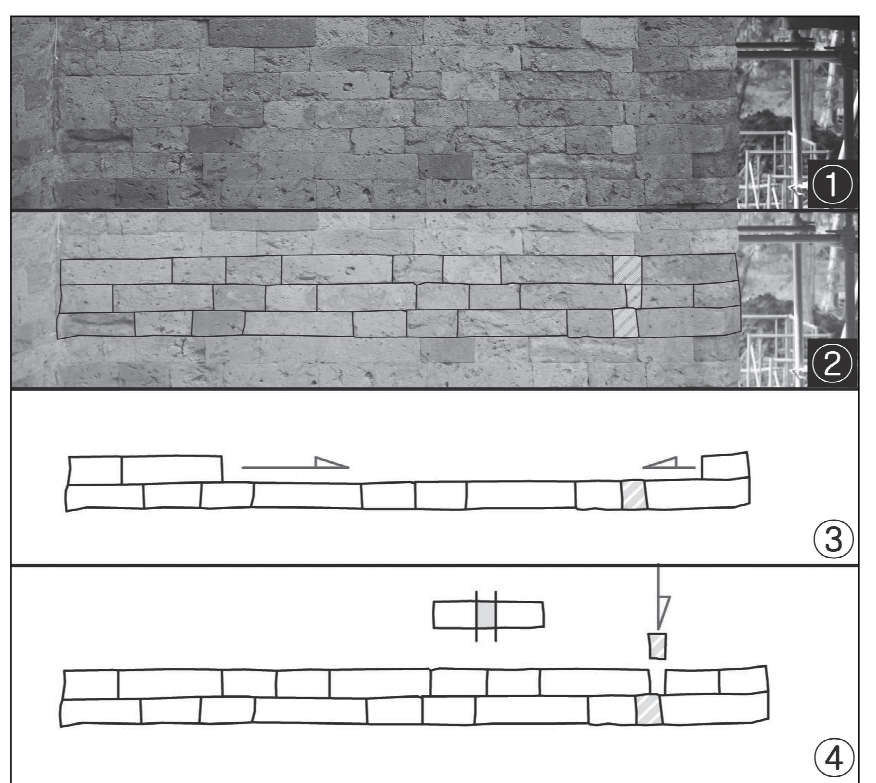

図 5 (1)N1 寺院の室内壁面 (内壁東面) (2)くさび用煉瓦 (斜線印)

(3), (4)煉瓦の組積順序、くさび用煉瓦の使用方法

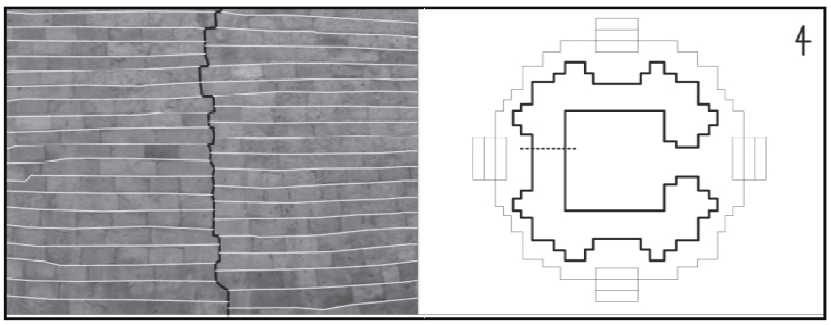

図 6 プレ・ルプ寺院内部壁面で観察される

区画整面加工例 (内壁西面) と区画分け箇所注6) 


\section{4. 整面加工}

研磨組積を用いて一層の煉瓦層を組積した場合、同じ層を構成す る各煉瓦の上面は不均一な状態であると考えられる。しかし、層間 の目地はほぼ平面になっている状態が観察される。すなわち、一層 の組積を完了した後、各組積層の上面は整面されたことが想定され る。

整面加工は遺構によって各層全体を通して上面を平坦に加工寸る もの (全体整面加工) と壁体を一定の区画に分けて加工するもの（区 画整面加工)に分けられる(図 6)。

\section{5. 水平化作業}

対象遺構では煉瓦層を組積する施工過程に発生した誤差を修正す るため適用された 2 種類の水平化の方法が観察された。

一つは建物全体の水平をあわせるために一定な高さの層全体に渡 り水平に合わせて整面加工が行われるものである。この技術が適用 された場合、該当煉瓦層の厚さは他の煉瓦層に比 べてより薄く施工 される場合が多い。本稿ではこの水平化の作業を一つの層全体にわ たって水平化するという意味で「層型水平化作業」と称する (図 7)。 もう一つの方法は、複層の煉瓦層を組み合わせて水平をあわせる方 法である。2 4 層にわたり作業が行われる場合が多い。本稿ではこ の水平化作業を「組み合わせ水平化作業」という (図 8)。水平化作業 層は各対象遺跡において地上レヴェルより $1.5 \mathrm{~m} \sim 2.5 \mathrm{~m}$ 程度の高さ で観察できる。

\section{6. 煉瓦の組積パターン}

他の文化圈における煉瓦造建築では煉瓦を一定のパターンで組積 する事例が多い。本項ではクメール煉瓦建築の組積パターンを理解 するために、対象となる遺跡の室内壁面と装飾が施されていない外 壁面を観察した。しかし、クメール煉瓦造建築では組積に特定のパ ターンが観察されにくく、観察できる場合でも厳密に適用されてい ないことが多い。本項ではそのような中にあっても規則性が確認で きた組積パターン 4 種類を示す。

\subsection{1. 小ロ方向組積 (図 9)}

煉瓦を交差して積み上げるコーナー部分以外の壁面で は小口面の みが表れる組積パターンである。観察対象の中にはロバン・ロメア スの K2 と K3、プラサト・プーム・プラサト (Prasat Phum Prasat), プレ・ルプの F4 と F5 で観察された。プラサト・プーム・プラサト とロバン・ロメアスの $\mathrm{K} 2$ 寺院は外装面すべてがこの積み方で組積 されているが、ロバン・ロメアスの K3 とプレ・ルプの F4, F5 では 必ずしも厳密に守られてはいないもののこのパターンにほぼ準拠し ている。

\section{6. 2. 長手 1 小ロ 2 繰り返し組積 (図 10)}

外壁面にて観察できる単一層内で、長手面が 1 回、小口面が 2 回 繰り返す組積パターンである。この方法は煉瓦 2 つを横にならべた ものを、一つの単位とし、90 度ずつ回転させながら積んでいたと考 えられる。サンボー・プレイ・クックの N8 寺院と N9 寺院、ロバ ン・ロメアスの K5 で観察できた。

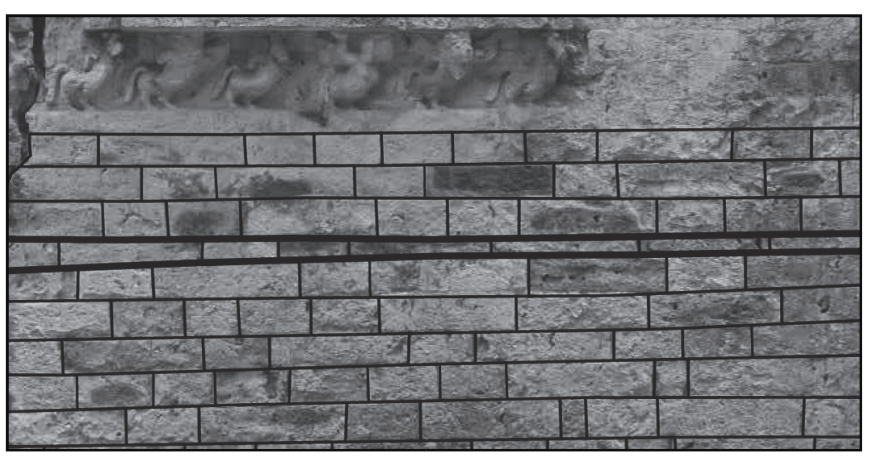

図 7 サンボー・プレイ・クック N7 寺院で観察できた 層型水平化作業（外壁北東面）

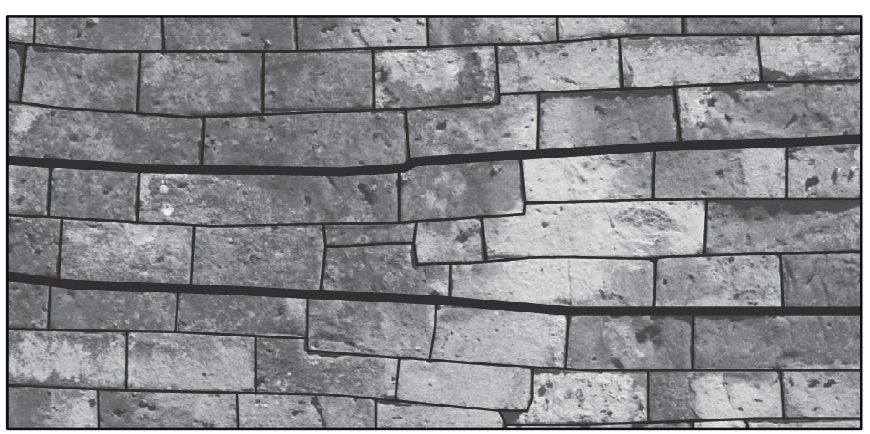

図 8 プレ・ルプ寺院で観察できる組み合わせ型水平化作業

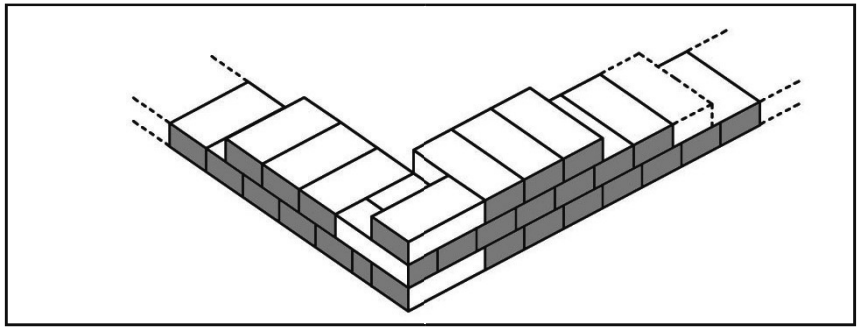

図 9 小口方向組積の模式図注 7)

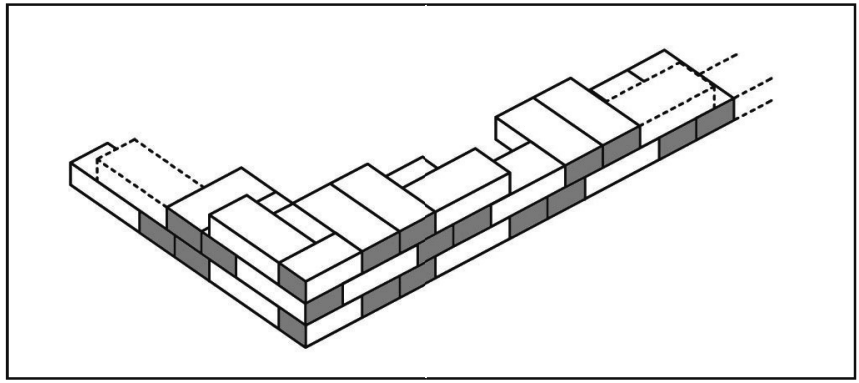

図 10 長手 1 小ロ 2 繰り返し組積の模式図

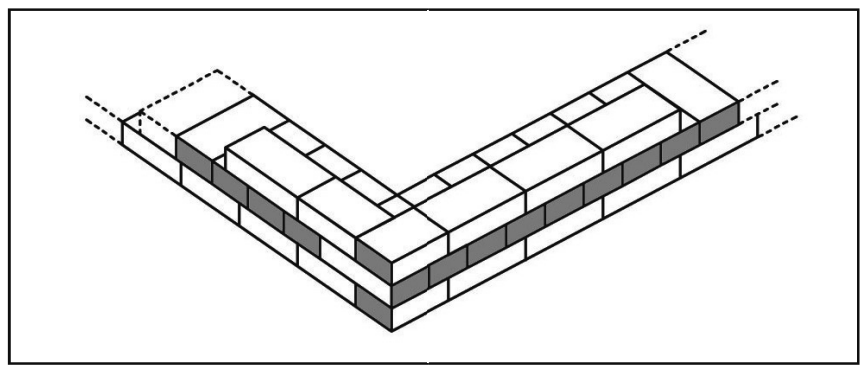

図 11 層間長手小口繰り返し組積の模式図 


\section{6. 3. 層間長手小口繰り返し組積 (図 11)}

外観上イギリス式組積と言われる組積方法と類似する組積方法で ある。組積パターンは、一層はすべて長手面を外面に積み、その次 の層は小口面を外にする。これを繰り返し積み上げる。プレ・ルプ の F2 と F5、ロバン・ロメアスの K6 で観察できる。

\section{6. 4. 直角交差組積 (図 12)}

外壁の角部分の垂直方向組積で観察できるパターンである。図 11 のように層が変わるたびに長手方向を 90 度ずつ交差する規則性を 持つ。崩壊が最も生じやすい角部分の安定性を高めるための組積方 法と見ることができる。このパターンも厳密に守られることはない が、調査対象のほとんどに傾向が見られる。

\section{7. モールディング箇所での小ロ方向組積}

段差が生じるモールディング部分、張り出し積みの層では小口面 が外に向かうように積み上げる規則が観察できる。これは張り出し 積みをする際に発生する構造的不安定を考慮した技術と考えられる。 長手面が外に位置する場合に比べ、小口面が外にある場合は力の中 心が壁体内部に位置するため、構造的に安定性が高くなる。この技 術は室内の天井を設置するための部分や、外壁の浮き彫り装飾の下 部、屋根の迫り出しが始まる起供部のモールディング (図 13)などで 観察できる。調查対象のほとんどでこの規則性が確認できた。

\section{8. 縦積みの煉瓦}

二層にまたがって縦方向に組積された煉瓦がごく一部観察できる (図 14)。この場合に一つの縦方向煉瓦は 2 つしくは 3 つの煉瓦層 にわたって位置される。プラサト・プーム・ウェアン，バコン (Bakong)の B4, プレア・コーP5, プレ・ルプの F4 と F5、ロバン・ ロメアスの K6 にて観察できた。

\section{9. 漆喰による外装装飾}

一部の煉瓦建築の外装には漆喰を用いた装飾の痕跡が見られる。 現存する外装面にて漆喰が観察できなくても風化による脱落の可能 性もあるし、観察されたとしても後補の場合もあろう。注8) 調查対象では 3 種類の漆喰塗布の煉瓦外壁面の加工方法が見られる。 1)壁面を平たく加工し付着する(サンボー・プレイ・クック $\mathrm{N} 1, \mathrm{~N} 8)$ 。 2)壁面にノミではつりの凹凸を作り付着する(バコン、プレア・コー、 プレ・ルプ)。3)壁面に小穴を穿ち付着する方法である(東メボン)。

\section{5. クメール煉瓦遺跡における組積技術の変化}

7 世紀〜10 世紀のクメール煉瓦造遺跡に用いられた組積に関する 7 種類の技術と 4 種類の組積パターン、そして漆喰による外装技術 について確認した。すべての対象遺跡で共通して観察される技術も あったが、特定遺跡だけで見られる場合、遺跡により変化が観察で きる場合もあった。本項では各技術の時代的変遷を考察する。

対象遺跡を時期により区別すると、7 世紀サンボー・プレイ・ク ック遺跡群、 8 世紀のコンポン・トムのプラサト・アンデット (Prasat Andet), プラサト・プーム・プラサと, 9 世紀のロルオス遺跡のプレ ア・コー、バコン、10 世紀はプレ・ルプと東メボンに分けられる。 また、追加考察のために $10 \sim 11$ 世紀に建てられたと考え

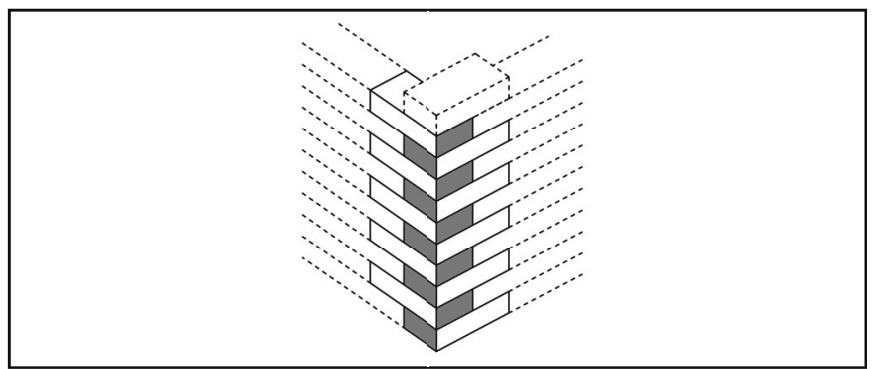

図 12 直角交差組積の模式図

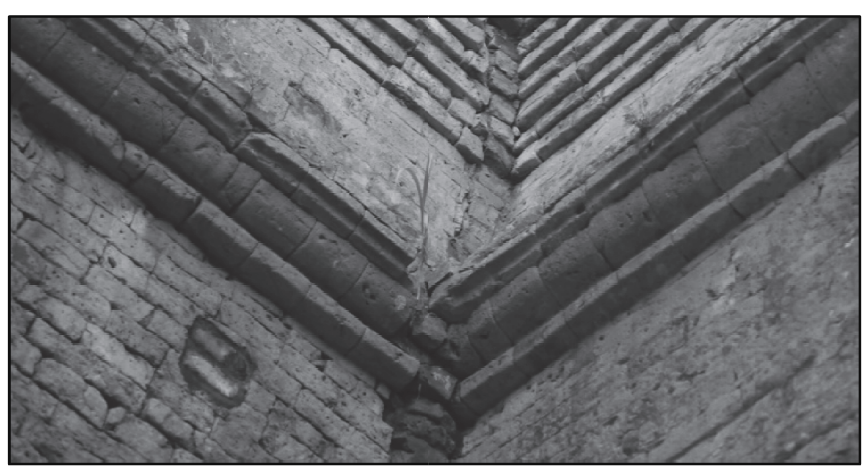

図 13 プレ・ルプ F1 寺院で観察できる小口方向組積 (内壁北東側)

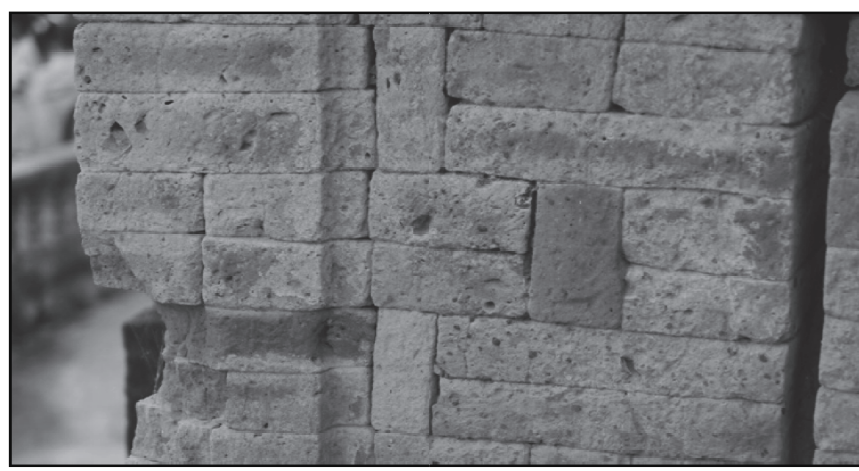

図 14 プラサト・プーム・ウェアンで観察できる縱方向組積 (外壁北面)

られているロバン・ロメアス遺跡を調查した。

考察は前項までに扱った各技術を対象にした。調査結果は表 2 の 通りである。「研磨組積技法(4.1)」、密着接着組積(4.2)」、「くさび 用煉瓦の使用(4.3)」は 7 世紀から 10 世紀にかけて普遍的に適用さ れながら、大きな技術変化が観察できないため、7〜10 世紀クメー ル煉瓦建築における最も基礎的な組積技術と見ることができる。ま た、「張り出しモールディング層での小口方向組積 (4.7)」も対象遺 跡すべてに適用されていたことが確認できた。この 4 つの技術は 7 〜10 世紀クメール煉瓦造建築を定義する基本的特徴として見るこ とができるだろう。「整面加工(4.4)」は前述したように建物全体に て同時に施す方法と区画を分けて施してから各区画を結合する方法 がある。 7 世紀〜8 世紀の対象遺跡には建物全体に渡る整面加工が 施された。9 世紀に入ってから区画を分ける整面加工技術が併用さ れる。全体整面加工は施工過程に精密な作業が必要となるが、そろ った目地が仕上がる利点がある。一方、区画整面加工技術は施工期 
間を短縮することができると考えられる。

「水平化作業 (4.5)」にも時期による变化が観察された。7世紀の 煉瓦造遺跡では主に層型水平化作業が施された。9世紀から組み合 わせ水平化作業が導入され始め、並用された。10 世紀には組み合わ せ水平化作業だけの事例も観察できる。この技術の変化も整面加工 の変化とともに煉瓦組積の区画化が影響していると考えられる。

煉瓦の組積パターンは観察できる事例が少なく、本稿では 組積パ ターンの時代的変遷を判断することは難しかった。直角交差組積は 7 世紀までは厳密に守られたが、後代には規則性が弱まった。

整面加工と水平化作業、直角交差組積の技術変化を見ると外観の 煉瓦組積方法の厳密性に対寸る保守性は弱まったと考えられる。

漆喰による外装技術も変化が見られる。漆喰を壁面に固着するた めに施された痕跡を時代毎に分けて見ると、ノミによるは凹凸もし くは固定のために開けた穴は後期の建物に集中寸る。9 世紀以後に 漆喰装飾の技術が発展し、使用頻度が多くなったと思われる。

以上の技術変化を総合すると 9 世紀に入って、漆喰を用いた煉瓦 建築の表面装飾技術が発展すると同時に、煉瓦を丁寧に積み上げ外 観を仕上げる必要性が減少した。したがって、「直角交差組積」のよ うな組積の規則性が緩み、施工性を高め、施工時間が短縮できる「区
画整面加工」と「組み合わせ水平化作業」という新たな技術が登場 したと考えられる。

このような 8 世紀末と 9 世紀初頭における変化はチェン・ラタに よる平面図、屋蓋部、壁体の変化があった時期とも重なるため、こ の時期の建築技術変化はより注目されるべきであると考えられる。

以上の技術的な展開が認められたが、10〜11 世紀の建立が推測さ れるロバン・ロメアスでは上記のような技術変遷は必ずしも当ては まらず、地域的な技術差があった可能性も推察される。また本研究 では対象遺構数が限られているため、より確実な技術編年の指標を 構築するためには調查遺構をさらに増やした追加調查が必要である。

\section{6. 結論}

7 10 世紀のクメール煉瓦造遺跡を観察し、煉瓦の組積に適用さ れた古代技術を明らかにした。また、建造年代による技術変化につ いて考察した結果、次のように整理することができる。

クメール煉瓦建築に使われた煉瓦の組積技術は、1)煉瓦と煉瓦を 研磨し、2)接着面が密着するように組積する。これにより、3)各煉 瓦の大きさが一定ではなくなり、各層の最終組積では余った隙間の 大きさに合わせたくさび用煉瓦が使われる。こうした過程は 7〜10

表 2 調査対象の時期別区別と時期による技術変化

\begin{tabular}{|c|c|c|c|c|c|c|c|c|c|c|c|c|c|c|c|c|c|}
\hline \multirow[b]{2}{*}{ groups } & \multirow[b]{2}{*}{ temple name } & \multirow[b]{2}{*}{ Period } & \multicolumn{7}{|c|}{ 枯瓦組積技術 } & \multicolumn{4}{|c|}{ 煉瓦組積パターン } & \multicolumn{4}{|c|}{ その他 } \\
\hline & & & 4.1 & 4.2 & 4.3 & 4.4 & 4.5 & 4.7 & 4.8 & 4.6 .1 & 4.6 .2 & 4.6 .3 & 4.6 .4 & 4.9 & & Size (L), & \\
\hline \multirow{8}{*}{ Sambor Prei Kuk } & N1 & \multirow{8}{*}{$7 C$} & 0 & 0 & 0 & A & $L$ & $\mathrm{O}$ & & & & & $5.0 \%$ & 1 & 274.8 & 144.0 & 76.3 \\
\hline & N7 & & 0 & 0 & 0 & A & $\mathrm{L}$ & 0 & & & & & - & 0 & 243.0 & 96.0 & 69.9 \\
\hline & N8 & & 0 & 0 & 0 & A & $\mathrm{L}, \mathrm{F}$ & 0 & & & 0 & & - & 1 & 284.6 & 147.0 & 80.6 \\
\hline & N9 & & 0 & 0 & 0 & A & $\mathrm{L}$ & 0 & & & 0 & & $0.7 \%$ & 0 & 274.8 & 143.2 & 73.9 \\
\hline & N10 & & 0 & 0 & 0 & A & $\mathrm{L}$ & 0 & & & & & $1.0 \%$ & 0 & 265.9 & 140.0 & 66.4 \\
\hline & \begin{tabular}{|l|} 
N11 \\
\end{tabular} & & 0 & 0 & 0 & A & $\mathrm{L}$ & $\mathrm{O}$ & & & & & $2.2 \%$ & 0 & & & \\
\hline & N12 & & 0 & 0 & 0 & A & L & 0 & & & & & - & 0 & 275.2 & 135.9 & 66.0 \\
\hline & N13 & & 0 & 0 & 0 & A & $\mathrm{L}$ & 0 & & & & & $2.3 \%$ & 0 & & & 69.5 \\
\hline \multirow{3}{*}{ Komphong Thom } & Prasat Andet & \multirow{3}{*}{$8 \mathrm{C}$} & 0 & 0 & 0 & $\mathrm{~A}$ & $\mathrm{~L}, \mathrm{~F}$ & $\mathrm{O}$ & & & & & $31.1 \%$ & 0 & & & 61.7 \\
\hline & Prasat Phoum Prasat & & 0 & 0 & 0 & - & - & 0 & & 0 & & & $40.7 \%$ & 0 & & & 67.8 \\
\hline & Prasal Phoum Weang & & 0 & 0 & 0 & - & - & 0 & 0 & & & & - & 0 & & & 44.5 \\
\hline \multirow{11}{*}{ Roluos } & Bakong B1 & \multirow{11}{*}{$9 \mathrm{C}$} & 0 & 0 & 0 & $\bar{A}$ & $\bar{L}$ & 0 & & & & & $2.7 \%$ & 2 & 249.3 & 125.4 & 40.2 \\
\hline & \begin{tabular}{|l|} 
Bakong B2 \\
\end{tabular} & & 0 & 0 & 0 & A & L & 0 & & & & & $37.9 \%$ & 2 & & & \\
\hline & \begin{tabular}{|l|} 
Bakong B3 \\
\end{tabular} & & 0 & 0 & 0 & $\mathrm{~A}$ & $\mathrm{~L}$ & 0 & & & & & $21.9 \%$ & 2 & & & \\
\hline & \begin{tabular}{|l|} 
Bakong B4 \\
\end{tabular} & & 0 & 0 & 0 & A & $\mathrm{L}, \mathrm{F}$ & 0 & 0 & & & & $40.4 \%$ & 2 & & & \\
\hline & \begin{tabular}{|l|} 
Bakong B5 \\
\end{tabular} & & 0 & 0 & 0 & A & $\mathrm{L}, \mathrm{F}$ & 0 & & & & & $31.8 \%$ & 2 & & & \\
\hline & \begin{tabular}{|l|} 
Preah Ko P1 \\
\end{tabular} & & 0 & 0 & 0 & $P$ & $\mathrm{~L}, \mathrm{~F}$ & 0 & & & & & $20.0 \%$ & 2 & & & 41.7 \\
\hline & \begin{tabular}{|l|} 
Preah Ko P2 \\
\end{tabular} & & 0 & 0 & 0 & $P$ & $\mathrm{~L}, \mathrm{~F}$ & 0 & & & & & $20.7 \%$ & 2 & & & 42.4 \\
\hline & \begin{tabular}{|l|} 
Preah Ko P3 \\
\end{tabular} & & 0 & 0 & 0 & - & $\mathrm{L}, \mathrm{F}$ & 0 & & & & & $28.3 \%$ & 2 & & & \\
\hline & \begin{tabular}{|l|} 
Preah Ko P4 \\
\end{tabular} & & 0 & 0 & 0 & $P$ & $\mathrm{~L}, \mathrm{~F}$ & 0 & & & & & - & 2 & & & \\
\hline & \begin{tabular}{|l|} 
Preah Ko P5 \\
\end{tabular} & & 0 & 0 & 0 & $P$ & $\mathrm{~L}, \mathrm{~F}$ & 0 & 0 & & & & $6.3 \%$ & 2 & & & 39.4 \\
\hline & \begin{tabular}{|l|} 
Preah Ko P6 \\
\end{tabular} & & 0 & 0 & 0 & - & $\mathrm{L}$ & $\mathrm{O}$ & & & & & $25.8 \%$ & 2 & & & \\
\hline \multirow{10}{*}{ Angkor } & Pre Rub F1 & \multirow{10}{*}{$10 \mathrm{C}$} & 0 & 0 & 0 & $P$ & - & 0 & & & & & $13.7 \%$ & 2 & & & 85.7 \\
\hline & \begin{tabular}{|l|} 
Pre Rub F2 \\
\end{tabular} & & 0 & 0 & 0 & $P$ & $\mathrm{~L}$ & 0 & & & & 0 & $10.9 \%$ & 2 & & & 81.0 \\
\hline & \begin{tabular}{|l|} 
Pre Rub F3 \\
\end{tabular} & & 0 & 0 & 0 & $P$ & - & $\mathrm{O}$ & & 0 & & & $8.6 \%$ & 2 & & & 87.0 \\
\hline & \begin{tabular}{|l|} 
Pre Rub F4 \\
\end{tabular} & & 0 & 0 & 0 & $P$ & $\mathrm{~L}, \mathrm{~F}$ & 0 & 0 & 0 & & & $17.1 \%$ & 2 & & & 78.4 \\
\hline & \begin{tabular}{|l|} 
Pre Rub F5 \\
\end{tabular} & & 0 & 0 & 0 & $P$ & - & 0 & 0 & & & 0 & $25.8 \%$ & 2 & & & 81.9 \\
\hline & \begin{tabular}{|l|} 
East Mebon Center \\
\end{tabular} & & 0 & 0 & 0 & A & $\mathrm{F}$ & 0 & & & & & $21.8 \%$ & 3 & 240.6 & 145.3 & 55.4 \\
\hline & East Mebon NE & & 0 & 0 & 0 & A & $\mathrm{F}$ & 0 & & & & & $25.0 \%$ & 3 & 268.5 & 183.6 & 75.6 \\
\hline & East Mebon SE & & 0 & 0 & 0 & A & $\mathrm{F}$ & 0 & & & & & $30.0 \%$ & 3 & & & \\
\hline & East Mebon SW & & 0 & 0 & 0 & A & $\mathrm{F}$ & 0 & & & & & $17.7 \%$ & 3 & & & \\
\hline & East Mebon NW & & 0 & 0 & 0 & A & $\mathrm{F}$ & 0 & & & & & $26.9 \%$ & 3 & & & \\
\hline \multirow{4}{*}{ Robang Romeas } & K3 & \multirow{4}{*}{$12 \mathrm{C} ?$} & 0 & 0 & 0 & A & $\bar{L}$ & 0 & 0 & 0 & & & $5.9 \%$ & 2 & & & \\
\hline & K4 & & 0 & 0 & 0 & - & $\mathrm{L}$ & 0 & & & & & $10.7 \%$ & 1 & & & 63.6 \\
\hline & K5 & & 0 & 0 & 0 & A & $\mathrm{L}$ & 0 & & & O & & $0.0 \%$ & 0 & & & 59.7 \\
\hline & K6 & & 0 & 0 & 0 & A & $\mathrm{F}$ & 0 & 0 & & & 0 & $4.3 \%$ & 0 & & & 58.4 \\
\hline
\end{tabular}

4.1 研磨組積 / 4.2 密着接着技法 / 4.3 くさび用煉瓦の使用 / 4.4 整面加工の範囲設定 A：建物全体にかける同時整面化, P： 区画整面化 / 4.5 水平化 作業方法 $L$ : 層型水平化, $F$ : 組み合わせ型水平化 / 4.7 張り出しモールディング箇所の小口方向組積 / 4.8 綎方向組積 / 4.6.1 小口方向組積 / 4.6 .2 長 手 1 小口 2 繰り返し組積 / 4.6.3 層間長手小口繰り返し組積 / 4.6.4 直角交差組積、表した数值は「交差率=例外層数/全体層数」であり、值が小さいほど 例外が少ないことを意味する。/Etc. Check 追加調査 / 4.9 漆喰の使用レベル $0 ：$ 観察できない, $1 ：$ 漆喰だけ観察できる, $2 ：$ 漆喰を付着するためのノミ 跡がある，3：漆喰を付着するための穴がある。/Brick Size 構成煉瓦の平均值(unit:mm) 
世紀すべての調查遺跡で共通して観察される。

各煉瓦層を組積する過程にて煉瓦層の上面を一定にする 4)整面 加工が施される。整面加工は建物全体にわたり一律に行われていた ものが、時代を経るにしたがって壁体を区画し、部分的に整面加工 を施した後、組み合わせる方法の併用へと移行する。

また、煉瓦層の水平を合わせるための技術として 5)水平化作業が 観察される。水平化作業も 2 種類の技術が観察できる。一つは層型 水平化作業で 8 世紀までの煉瓦造遺跡で広く観察できる。もう一つ は組み合わせ水平化作業であり、9世紀以後の煉瓦遺跡で広く見ら れる。

漆喰を固着させるための技術は 3 種類ある。平らな壁面にそのま ま塗布する方法、ノミを用いて凹凸を作って塗布する方法、穴を開 けて塗布する方法である。この技術も時期による区別が可能であり、 漆喰を固着するための凹凸と穴は 9 世紀以後の遺跡で主に見られる。

上記した整面加工と水平化作業、漆喰を固着するための技術変化 がおきる時期はいずれも 9 世紀である。整面加工と水平化作業の技 術の特徴からみて、8 世紀までには建物全体にわたる組積が行われ たが、9世紀からは建物を区画して組積する方法に変化したと見る ことができる。 8 世紀までは煉瓦積みよる美観意識が高かったもの が、9 世紀になると施工性を求め、施工期間がより短縮できる技術 へと変化したものと考えられる。このような流れは、漆喰装飾がよ り一般化したこととも関係すると思われる。

本研究で考察した通りに、クメール煉瓦造建築に適用された技術 は 9 世紀を基点とし多くの変化が認められる。つまり、10 世紀半ば をクメール煉瓦造建築の絶頂期とみられるなら、9 世紀初頭をクメ 一ル煉瓦造建築の変革期として見ることができるだろう。

しかし、技術による厳密な編年には地域性などを考慮した上で、 より多くの遺跡を対象に追加研究する必要があろう。本研究で判明 した古代煉瓦組積技術の変化の傾向は、クメール煉瓦遺跡の保存修 復において当初技法を順守し，その特質を後世に継承する上でも有 効であると期待される。

\section{参考文献}

1)DUMARCAY, J. : Construction Techniques in South and Southeast Asia, p.54, 2005

2)REINCKE,A. et al : The first golden age of Cambodia, 2009 3)チェン・ラタ: クメールレンガ造建築の構造技術の発展過程, 日本建築学会 計画系論文集，第 73 巻，第 627 号, pp.1097-1103, 2008.5

4)重枝豊: チャンパ祠堂の壁俞の種類と配置について、日本建築学会計画系 論文集，第 487 号，pp.215-223, 1996.9

5)DUMARCAY, J., ROYERE, P. : Cambodian Architecture, Eight to Thirteenth Centuries, p.13, 2001

6)CROCI,G. : Angkor Charter, UNESCO, p.47, 2013

7)CROCI,G. : Angkor Charter, UNESCO, p.48, 2013

8)MASSARI, I. : The Preah Ko Temple : Emergency Consolidation at Angkor Cambodia PhaseII, RAF,1995

9)DUMARCAY, J., ROYERE, P. : Cambodian Architecture, Eight to Thirteenth Centuries, p.13, 2001

10)チェン・ラタ:クメールレンガ造建築の構造技術の発展過程と構法上の特 徵の解明に関する研究, 日本建築学会計画系論文集, 第 73 巻, 第 627 号, pp.1097 1103, 2008.5

11)チェン・ラタ:クメールレンガ造建築の構造技術の発展過程に関する研究, 日本建築学会計画系論文集, 第 74 巻, 第 642 号, pp.1875-1884, 2009.8 12)重枝豊 : チャンパ王国の宗教建築における建築技術に関する史的研究、日 本大学博士学位論文、1999

13)HOANG,B.C. : Ancient brick productive kilns found at Cat Tien,
Southern Vietnam, Khao Co Hoc, 2008(太田千香子訳 : ベトナム南部カッ ティエン遺跡の古代レンガ生産羹, 東南アジア考古学, 29 号, pp.79 86, 2009)

14)大川智也 : サンボール・プレイ・クック遺跡の建材とその劣化に関する研 究, 早稲田大学修士論文, p.19, 2006

15)PARMENTIER,H. : L'art khmer primitif', 1927

16)PARMENTIER,H. : Complémenté L'art khmèr primitif, BEFEO, Tome 35, Hanoi, 1935

17)JACQUES,C.\&LAFOND,P. : The Khmer Empire -Cities and Sanctuaries from the 5th to the 13th century-, 2007

18)重枝豊 : チャンパ王国の宗教建築における建築技術に関する史的研究, 日 本大学博士論文, 1998

19)崔炳夏 : クメール王朝アンコール期の宗教建築における建築構法の発展に 関寸る研究, 日本大学博士論文, 2001

20)チュンメンホン：都城の基本構造と関連する寺院遺構の建立と利用年代 クメール古代イーシャナプラの都市構造に関する研究その 1 , 日本建築学 会計画系論文集, 第 78 巻, 第 690 号, pp.1865-1874, 2013.8

21)下田一太 : 初期クメール複合寺院,プラサート・サンボーの改変, 日本建築 学会計画系論文集, 第 73 巻, 第 628 号, pp.1363-1370, 2008.6

22)CHIM,P. : The Conservation and Restoration of the Six Towers at the Preah Ko Site, forth symposium on the Bayon, JSA, pp.147-162, 1999

23)RUNKEL,S. : Interior Polychromy and Wall Paintings in Khmer Brick Temples of the 9th and 10th Century in Cambodia, Connecting Empires and States, pp.276-289, 2012

24)下田一太: クメール古代都市イーシャナプラの研究、早稲田大学博士論文、 p.185、2010

注

注 1) RAF は Preah Ko 寺院の修復に適用した接着剂にヤシ砂糖を混合したこ とを報告している(I.MASSARI : The Preah Ko Temple, Emergency Consolidation at Angkor Cambodia phase II, RAF,1995)。

注 2) サンボー・プレイ・クック遺跡は多数の煉瓦遺跡で構成される複合遺跡 である。主要遺跡の多くは 7 世紀に建立されるたようだが，8,9 世紀を中心 に断続的に 14 世紀まで増改築・周壁等の補助施設を追加、また周辺への新 たな建設工事が続いた。本研究では 7 世紀に建てられた遺跡だけを対象と する。

注 3)Robang Romeas の K4 塔の K.153 と番号付けられている碑文はスーリ ヤヴァルマン 1 世の名が記されているため、この寺院は彼の治世期の 11 世紀だと考える意見もある。しかし、碑文が刻まれた扉枠は増築部の前室 であるため、寺院の建立時期を定める事はできない。

注 4) Sambor Prei Kuk と Robang Romeas の遺構番号は(PARMENTIER,H. : L'art khmer primitif, EFEO, 1927)を参照した。他の考察対象遺構のみ、 筆者が臨時的に付けた。

注 5)調査対象の図面は現地でのスケッチとガイドブックを参照して書いた簡 略平面図であるため、正確ではない部分がある。

注 6)白い横線は煉瓦の層位、黒い線は煉瓦壁体の区画が別れる箇所を示して いる。平面図は模式図である。

注 7)この模式図では外側の組積構造だけを表している。模式図も理解のため に、小口面を黒塗した。

注 8）サンボー・プレイ・クックの $\mathrm{S} 10, \mathrm{~N} 21$ では, 漆喰装飾と下地の彫刻が 異なるため、建立完成後に外装が変更されたものと考えられる。 


\section{THE STUDY OF ANCIENT TECHNIQUES ON KHMER BRICK TEMPLES}

\section{Donghee PARK*, Takeshi NAKAGAWA** and Ichita SHIMODA***}

* Research Fellow of the Japan Society for the Promotion of Science/Laboratory of Architectural history Waseda Univ. Ph.D. Candidate. Eng
** Prof. of Faculty of Science \& Engineering, Waseda Univ., Dr. Eng *** Assist. Prof., Graduate School of Comprehensive Human Science, University of Tsukuba, Dr. Arch

\section{Purpose of study}

From 7 to 10th century, the religion architecture was formed by bricks actively in Cambodia. The ruins are still remained but the succession of technique is disconnected and this situation leads to a hard restoration. This study focuses on the masonry construction techniques among the ancient techniques used on Khmer ruins and determines what kinds of techniques were introduced. Furthermore, this study considers how each technique had been used and changed with the times.

\section{Object of study}

The object of investigation is the 36 of Khmer brick ruins(fig.1) from 7th to 10th century. 10 shrines were built in Sambor Prei Kuk at 7 century, 3 shrines at 8 century in Kompong Thom province, 5 shrines in Bakong temple, 6 shrines in Preah ko Temple at 9 century, 5 shrines in Pre rup temple, 5 shrines in East mebon Temple at 10 century. Lastly, 4 shrines in Robang Romeas is unknown the period.

\section{Method of study}

This study is based on the field survey because most of ancient Khmer bricks construction techniques are slipped away.

\section{Ancient techniques on the Khmer brick shrines}

According to the survey result, there are 8 brick laying techniques and 4 brick laying patterns. 8 Laying techniques are 'polishing laying technique', 'sticking laying technique', 'completed brick technique(fig.4, fig.5)','flat surface technique(fig.6)', 'leveling technique(fig.7, fig.8)', 'projected molding technique(fig.13)', 'vertical laying technique(fig.14)'. And 4 laying patterns are 'all short faced pattern(fig.9)', '1long-2short faced pattern(fig.10)', 'short and long repetition faced laying pattern by layers(fig.11)', 'crossing corner laying pattern(fig.12)'.

\section{Change on techniques (table.2)}

Techniques can be distinguished into common techniques over the every year and changed techniques by lapse of time. 'polishing laying technique', 'sticking laying technique' and 'the completed brick technique' are common technique. The other hands, we observed changes from some techniques which are 'flat surface technique' and 'leveling technique'. On the paper, we consider the change have been happened around 9 century. And it is supposed that the change is related with exterior techniques. Because, plaster mortar technique have been developed around 9 century. And it looks affect to brick laying patterns also. 